\title{
The Ignored Skill in EFL Context "Listening": A Review of Selected Article by Omar Gokhan Ulum
}

\author{
Sandra Yunira \\ Vocational High School 5, Pekanbaru, Indonesia \\ sandrayunia98@gmail.com
}

\section{ARTICLE HISTORY \\ Received : 5 May 2019 \\ Revised : 25 May 2019 \\ Accepted : 27 May 2019}

\section{KEYWORDS}

\author{
Listening \\ Ignored Skill \\ Root of Problem \\ Article Review \\ English as a Foreign Language
} (EFL)

\begin{abstract}
This paper aimed at reviewing the selected article entitled "The ignored Skill in EFL Context" written by Omer Gokhan Ulum. This study sees Ulum's article as a unique study and essential to explore the difficulties of listening comprehension faced by students of the first-year university with elementary level English. Ulum's research involved $50 \mathrm{EFL}$ students from three different classes. The data was accumulated by interview and a set of questions. The outcome of the study showed that EFL students find it hard to understand the listening when people speak with numerous and uncommon accents. Also, the students do not have the skill to understand the meanings of words which are not pronounced accurately. This present study concluded that the students' inability to quickly memorize the words or sentences that they have just overheard is highly likely to be the reason why the listening skill is considered as an 'annoyance' for the EFL students in the study. These results may help EFL teachers in boosting students' listening comprehension skills. As an outcome, this present paper may say that Ulum's article can be replicable onto similar research topics, especially on the methodology section.
\end{abstract}

\section{Introduction}

The initial line of thinking of this paper was by the strong perspective of the listening skill as the biggest problem and often the weakest skill of the students who learn English as a Foreign Language (EFL). Major problems of learning the listening skill has been identified to include the students' lack of control over the speed at which speakers speak, inability to ask for repetition, limited vocabulary and lexicon, failure to recognize the signals or cues, inability to quickly interpret what is being heard, inability to concentrate, and possessing an established learning habits that do not actually support the students' listening skill progress (El-Dali, 2017; Kasriyati, 2019; Syaifullah, 2019). These "belief barriers, material barriers, habitudinal barriers, information processing barriers, English proficiency barriers, strategic barriers and affective barriers" are what makes students from generations continue to face problems in mastering the listening skill for years (Gilakjani \& Sabouri, 2016; Yilmaza \& Yavuza, 2015). This situation exists in the teaching and learning process of English listening skill, common among native English students and even more common among non-native English students. Therefore, this paper intended to review of one selected article in the EFL listening context: "The Ignored Skill in EFL Context" written by Omer Gokhan Ulum (henceforth: Ulum) published in May 2015 in the International Journal of Humanities Social Science and Education (IJHSSE).
Omer Gokhan Ulum is an academician at Hakari university, Turki. His study concern is in EFL teacher consent, EFL teacher improvement, EFL strategy, EFL program assessment, language skill, coursebook assessment and linguistic. He is the writer of many books for EFL papers. He is a Faculty Member of Adana Science and Technology University. He is the author of "Recep Tayyip Erdogan, Akademic Yds \& Universal Grammar: Building Proficiency in English Grammar". The aims of this paper are to analyze the listening issues of a group of college students who are studying basic level EFL courses at Hakkari University, Turkey.

According to Hichem, 2013, "listening is a study that most complicated and difficult to be analyzed. It means that it is hard to comprehend with clarity." Andrade (2006) said listening could be referred to as one of the four key skills through which a language is taught, and it is one of the two language skills that is used when communicating orally. Listening is a pedagogical term refers to 'speech recognition', 'speech perception', 'speech understanding' and 'spoken language understanding" (Huei-Chun, 1998). It is a very active process means that when we listen not only we deal with what we listen or hear but also we combine it with other information that is already familiar" (Helgesen \& Brown, 1995; Helgesen, 2003). As a consequence, by means of this active process, we create the meaning by integrating what we hear or experience with the data in our minds. 
Language structures, reading comprehension, vocabulary, and writing are some of the highest priorities of the English course. The course intends to make students become very excellent in the translation from one language into another language (Lotfi, 2012; Solak \& Altay, 2014). Regrettably, listening skill is unnoticed in the English program practice. As a result, when these students are suddenly faced with more established or multifaceted listening courses or audio listening implements at universities, they find themselves in huge issues relating to communication that lasts till graduation (Hamuddin, 2016; Sari, Putri, Herdi, \& Hamuddin, 2018). This calls for connected research on the listening complications of EFL learners.

\section{Literature Review}

According to Nowrouzi, Tam, Zareian and Nimehchisalem, 2015 "EFL listening skill is regarded as a problematic language skill, especially in a foreign language context where real practice chances are narrow." According to Ghaderpanahi, 2012 "Teaching the listening skill to students may be difficult for teachers and certainly difficult for students to learn it as well. For example, even the students who are capable of speaking and reading might confront problems with listening skill when facing a record with a quick conversation." According to Tyagi (2013), the listening process takes place in five steps of hearing, namely receiving, understanding, remembering, evaluating, and responding.

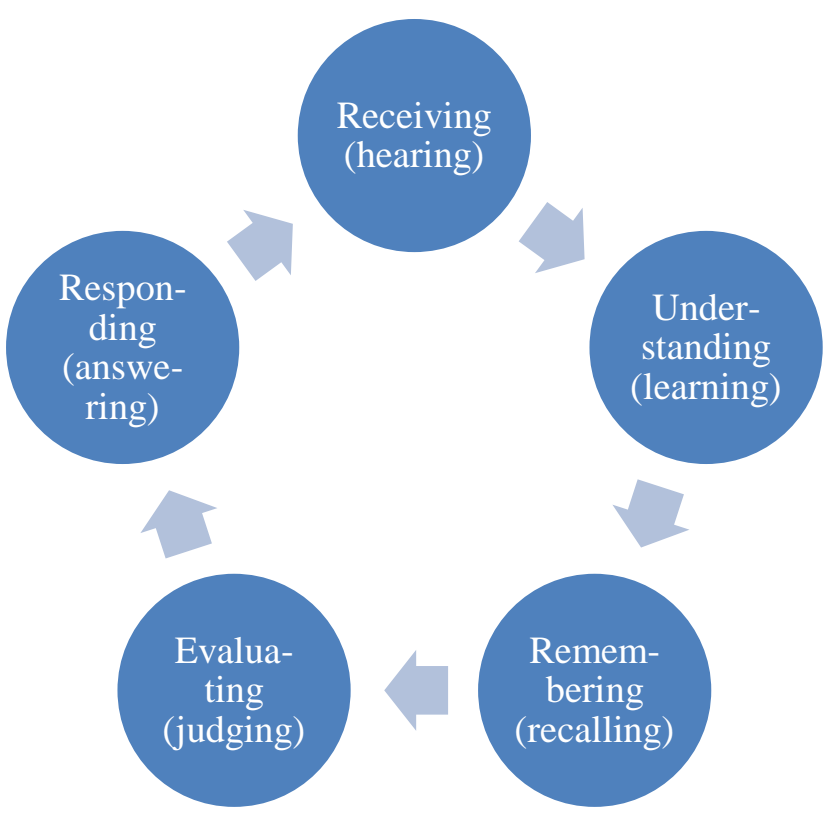

Figure 1. The Listening Process and Its Five Aspects
Tyagi (2013) stated that "hearing is the realization of sound waves; at first you must hear to listen, but you don't need to listen in order to hear, understanding means the understanding of symbols that we have seen and heard, we should look at the meaning of the stimuli that we have to know, remembering means that a person has not only approved and make clear a message but has also added it to the brain, evaluating necessitates the active listener to make sure proof or classify fact from opinion, and specify the existence or non-existence of bias in a message, responding requires that the receiver completes the process by means of verbal or nonverbal feedback."

Moreover, according to Tyagi (2013), cited in Ulum's article, listening skill consists of some important parts such as:

a. Recognizing words and understanding meaning

b. Identify the structure of grammatical of the word

c. Connecting linguistic sign to non-linguistic and paralinguistic sign

d. Discriminating between sounds

e. Identifying expressions meant to create meaning

In addition, according to Ziane (2011), "the listening skill needs more focus, and a quick understanding is also required. When listening, many points should be specifically paid attention. They are context, facial expressions, and body gestures that are very important for the listeners to facilitate the understanding of what is transferred by speakers.” Kline (1996) has divided listening into 5 types:

a. Listening is a situation where the based concern of listeners is to comprehend the meaning. Listeners are successful in understanding the meaning that which the sender intended.

b. The relation of listening is either to help a person or to improve the relationship between people.

c. Appreciative listening includes listening to music for fun, to speakers because you like their style or accent, to your choices in theatre, radio, film or television. It is the answer of the listener, not the basis of the message, which defines appreciative listening. That which provides appreciative listening for one person may provide something else for another.

d. Critical listening is the skill to listen critically. The subject of critical listening justifies much attention than we can give.

e. Discriminative listening is the skill to separate among the different sounds. It may be the most important type, and it is primary to the other four. By being sensitive to changes in the speaker's force, pitch, rate, volume, and emphasis, the instructive listener can detect of difference in meaning 


\section{Method}

Using a qualitative approach, qualitative Approach is a study about descriptive and tend to use analysis, the process and meaning (the perspective of the subject) it more highlighted in the qualitative approach, Qualitative research tends to try to cover the reasons for behaviours, attitudes instead of the details about what, when and where. Analyzing and interpreting the journal based on the themes or perspectives. In other words, quantitative research is research that used to measurements the existence of a variable by using research instruments, then followed by statistical analysis. Descriptive research is research that seeks to describe and classify facts of characteristics of phenomena that are examined factually and carefully. The writers are trying to go beyond the usual analyze model by presenting procedures that are more detailed in each of their research strategies. For example, a grounded theory strategy has systematic steps in analyzing the data. These steps include making the categories of information obtained (open coding), selecting one category and placing it in one theoretical model ( axial coding), then assembling a story from this inter-category relationship ( selective coding). In addition, to grounded theory, case of studies involve detailed descriptions of certain settings or individual, which are then followed by data analysis.

This study analyzed an article entitled "Listening: The Ignored Skill in EFL Context “ wrote by Ömer Gökhan Ulum, which is published in the International Journal of Humanities Social Sciences and Education(IJHSSE). Volume 2, Issue 5, May 2015, PP 72-80. This selected to be reviewed due to develop listening skill competency of students. The article discussing data is taken from Hakkari University basic level EFL learners studying in the first classes of the Child Development Department. Listening skill is ignored in the English Test. The article consists of 14 pages.

This study focuses on and exploring the article to see whether the article can contribute significantly to academia. Further, this review study also would like to reveal the strengths and the weaknesses of the article which can help to distinguish the article can be replicable or being a good reference in this scope of a research field.

\section{Results \& Discussion}

Ulum's article seems in line with Rost (1994) and Ziane (2011) who mentioned that "listening comprehension is the most essential because it is a process through which we get input and without its comprehension learning does not happen." As well as Doff (1995) and Ziane (2011) in terms of idea on "especially that listening has a personal effect on developing speaking. That is, we cannot improve our speaking skill unless we improve our listening skill. If a learner has a good listening skill $\mathrm{n}$ English language, it would be very easy for him to listen to the radio, to study, watch films, or communicate with foreigners. Learners should have a lot of practice and subjection to English in order to develop this ability. There is a relationship between listening to a language and learning it. If we compare two learners; one is living in a country where the target language is the first language, and the other is living in a country where English is only spoken in academic places. The difference is that the first learner can receive English more easily, effectively, and quickly than the second one. As a consequence, learners need as much exposure to the English language as possible."

Ulum also supports Hedge (2001) "listening has an essential role in life, and when people are engaged in communication nine per cent is spent to writing, 16 per cent to reading, 30 per cent to speaking, and 45 per cent to listening which shows the significance of listening in the communication process." According to Lundsteen (1979) "expressed that listening is the first skill to appear. He continued that children listen before they speak." According to Hedge (2001) "indicated that modern society likes to change from printed media towards the sound and its members. Consequently, the significance of listening cannot be ignored. He emphasized that listening is of great importance in the English language classroom."

Furthermore, according to Sheila Steinberg from her book entitled "An Introduction to Communication Studies" in the year 2007. She wrote that, "Listening is more difficult than only hearing. It is a procedure that contains four steps: knowing and attending, understanding and interpreting, remembering, and responding. The steps occur in categorization, but we are generally unaware of them". While, Thomlinson (2002) defines listening includes "active listening, which goes beyond comprehending as understanding the message meaning as an act of emphatic understanding of the speaker". Furthermore according to Saha (2008) expresses that "even though hearing and listening are related, listening includes an active process, which needs analysis of sounds, in the opposite, to hearing that only notice sounds in a passive way". Hence, Ronald and Roskelly (1999) also define listening as an active process requiring the same skills of prediction, hypothesizing, checking, revising, and generalizing that writing and reading demand; and these authors present specific exercises to make students active listeners who are aware of the "inner voice" one hears when writing.

Ulum is also seeing the idea of listening which this study believes is quite similar to what Hamouda (2012) expressed in his study about how listening is a receptive skill. This means that people obtain the main idea according to what they hear. Aside from that, according to Helgesen (2003) supports that "listening helps the learner to be "flexible listeners", to know how to listen in order to get a general idea or the specific information needed to understand videos" and also quite similarly, Rubin (1994) argued that "although listening is a passive skill it is very much an active process of selecting and interpreting information from auditory and visual clues". 
According to Rubin (1994) says that "the listening skill is conceived of as an active process in which listeners select and interpret information which comes auditory and visual clues to define what is going on and what the speakers are trying to express." Rubin (1994) completes her definition by saying that "active means listeners get information from visual and auditory clues and relate this information to what they know. Select means that in the process of making sense of the input, listeners use only part of the incoming information. Interpret means that in trying to make sense of the input, the listener uses their background knowledge as well as the new information of what is going on and to figure out what speakers intend listening influences other skills. Tomatis shows that the quality of an individual's listening ability will affect the quality of both their spoken and written language development." She also views that "if the sounds of the target language are presented to the learners before presenting them in written form, the ease with which they integrate those sound will be reflected in their understanding and production of the language."

In his article, Ulum stressed that listening is one of the most important skills in the second position after mastering the language, namely English. However, so many students that still get hard to face the difficulties of listening English. The difficulty occurs because English is not their mother tongue or national language in turkey. Even some people and students call this English is a foreign language for them. Therefore it is not surprising that understanding listening English is one of the difficulties faced by students.

Meanwhile, learning a second language, namely English, turned out to have a significant problem. Because in listening comprehension, the school pays more attention to structure, writing, reading, and vocabulary. For some people, listening is not an important part, by learning books or syllabus, and most teachers are not concerned while preparing for the learning. A large number of teachers believe that it will develop naturally in the language learning process, and they will learn without realizing it.

In some cases, this is more important than reading, speaking, and writing. In fact, without listening effectively, learning is a matter of chance. Listening strategies teach listening to students is very helpful, and it is all the task of the teacher/educator. But it is not enough unless the teachers increase student vocabulary, grammar, and phonological knowledge. Development strategies are also important for listening to training because the strategy is a conscious means by which learning can guide and evaluate their understanding and responses. There are many cognitive, metacognitive and socio-affective strategies. The strategies can change according to student level. A cognitive strategy is a strategy used to understand linguistic input and obtain data. Students sometimes do not know the meaning of words and they try to guess the meaning of the context. Cognitive strategies connect to understand and collect input from short-term memory or long-term memory for further access. Metacognitive strategies in this strategy students are aware when listening to the text carefully. This method relates to learning how to plan, monitor and assess the information collected from the part of hearing just like the previous listening activity.

\subsection{Strengths}

This journal is written by Omer Gokhan Ulum, in this journal discuss "Listening: The Ignored Skill in EFL Context". It will be beneficial because so many research that leads to listening problems. The material on this paper is a complete look at the sub-Headings in this paper are detailed. The excess of this paper is that the author can develop some of the important points to be studied, and the author does it pretty well. This paper clearly explains the definition of listening, The Listening Process, review of literature, analysis for EFL listening, essential elements and the significance of this study. The parts in this journal are detailed and organized, Clear in reflecting the content. The introduction of this study has already explained why this research is important. This study focuses on and exploring the article to see whether the article can contribute significantly to academia. By the title, we can know what's the topic about. Because it's easy to understand, the author also mentions that this study aims to make readers comprehend an expansive view and in-depth knowledge as to the comprehension of how the basic level EFL learners at Hakkari University know listening issues in EFL courses and to recognize the view of basic level EFL learners in terms of pre-established standard. The authors, including the keyword to help readers understand this journal. And then, the authors also mention much material, so the readers get the complete information about listening.

The abstract clearly describes the summary of information. The data that collected in this journal is complete because there are data from various experts from the listening field. The diction of this paper is strongly good, so the readers can more comprehend easily in every meaning of a word. The data that mentioned in this paper is clear, and the author also lists some questionnaire that supports the data. The presentation of the data is already put in the form of sentences and images. So it is easy for readers to understand the contents of this paper. The theory used in this paper is related to the aim of this paper. And the discussion in accordance with the method.

This paper is written by the book of article writing. The author includes a reference, so the readers could get many references about the listening problem and make this article as a reference for readers who want to use this journal. The author includes the image of " the process of listening" so that the reader can describe it clearly. The discussion of the method used is very clear, and the abstract clearly, so that by reading the abstract, readers can find out the result of the study. The author also mentions the importance of listening skill. The result of his research is good. The selection of the titles is very interesting. The author lists the suggestions for further research. 


\subsection{Weaknesses}

The data that collected on this paper is too difficult to understand for the readers who have low comprehension will get hard to analyze the data. Though the data collection in this journal is complete. It will be better if the writer expands the sample since the current data is too small to make a general conclusion. Besides, further research needs to be done with more comprehensive samples, including different levels of English comprehension and different English learning contexts to obtain a bigger picture of the problem. For the explanation on this paper, there are some points that explained clearly by Tyagi should explain one by one, so the readers won't get confused. One of the points, discriminating between sounds, the beginner readers don't understand it too much and should elucidate it clearly. There is too much topic on this paper so it can not focus on one topic. The journal should include the place and years of research, so readers know the place of research and what year this journal is researched.

\section{Conclusion}

Try to learn how to listen, and after that, we know how to speak as well. Listening is essential in EFL class as it deliveries the learner with input. If we don't develop strategies to help the learners to comprehend the needed input, then learning doesn't occur. Listening is the inclusion of the meanings of words and sentences by the brain. Listening leads to the understanding of facts and ideas. But listening takes attention, or push to the task at hand in the feeling of disturbance. It needs concentration, which is the focusing of your thoughts upon one particular problem. A person who absorbs listening with concentration is actively listening. Active listening is a method of responding to another that stimulate communication. Listening skill has been ignored in the EFL context, as well as being undervalued in study literature when related to other skills of English. David Nunan explains "listening skill as Cinderella skill in EFL context." listening more dominant than others.

Listening comprehension is strongly being the lacking skill of EFL learners who face the listening skill. This study appears with the aim of finding the elements that cause the learners" listening problems". So, the conclusion is summarized in two points:

a. EFL learners find it hard to understood the listening context when speakers speak with varied form and unfamiliar accents.

b. EFL learners find it hard to know about the meanings of words which are not pronounced clearly.

Moreover, listening skill is the biggest obstacle for students that are weaving education. It was their lack of skill among other language skills. They faced many problems in listening task activities, and they didn't have the desired chances to apply the listening skill. Most of the learners were not shown to a native speaker of English.
So, educational institutions should not only pay attention to the structure of writing, reading and vocabulary but also must pay attention to the terms of listening comprehension. A learning goal will not be reached if all aspects are not considered properly and correctly. Listening is also an important part of learning because if students are not able to listen well, how they will understand what is speaker said or what is explained by the educator when delivering a learning material using English. In addition, if students are unable to understand, how can they interact and communicate using English properly and correctly if what they are listening to is not understood.

\section{Acknowledgement}

This research was supported by SMKN 5 Pekanbaru. Therefore, the authors would like to express their sincere gratitude. Any opinions, findings, and conclusions or suggestions expressed in this material are those of the authors and do not necessarily reflect the views of the respected institution.

\section{References}

Andrade, M. E. A. D. (2006). Improving how listening skills are taught in the EFL classroom: Guidelines to producing better speakers of the English language (Bachelor's thesis).

Doff, A. (1995). Listening. Level 4: Cassette 2: 2. Units 12 20. Cambridge University Press.

El-Dali, M. (2017). L2 listening comprehension: is it a language problem or listening problem. English Linguistics Research, 6(1), 14-37.

Ghaderpanahi, L. (2012). Using Authentic Aural Materials to Develop Listening Comprehension in the EFL Classroom. English language teaching, 5(6), 146153.

Gilakjani, A. P., \& Sabouri, N. B. (2016). The significance of listening comprehension in English language teaching. Theory and Practice in Language Studies, 6(8), 1670-1677.

Hamouda, A. (2012). Listening Comprehension ProblemsVoices from the Classroom. Language in India, 12(8).

Hamuddin, B. (2016). Using Content Analysis (CA) in Seeking the Opportunities for Alumni of English Department in Newspapers. ELT-Lectura, 3(1).

Hedge, T. (2001). Teaching and learning in the language classroom (Vol. 106). Oxford, England: Oxford university press.

Hegelsen, M. (2003). Listening In Practical Language Teaching. New York: McGraw Hill. 
Helgesen, M., \& Brown, S. (1995). Active Listening: Introducing Skills for Understanding: Student's Book. Cambridge University Press.

Hichem, B. (2013). An investigation on listening challenges facing EFL learners (Doctoral dissertation, MA Thesis. Mohamed Khider University of BISKRA: Algeria).

Huei-Chun, T. (1998). A study of EFL listening comprehension strategies. Eric Journal, 1-19.

Kasriyati, D. (2019). Using Video To Teach Listening at English Department in Fkip Unilak Pekanbaru. $J$ SHMIC: Journal of English for Academic, 6(1), 1-7.

Kline, J. A. (1996). Listening effectively. Air Univ Press Maxwell Afb Al.

Lotfi, G. (2012). A questionnaire of beliefs on English language listening comprehension problems: Development and validation. World Applied Sciences Journal, 16(4), 508-515.

Lundsteen, S. (1979). Listening: Its impact on language and the other language arts. Urbana, IL: ERIC Clearing House on Reading and Communication Skills.

Nowrouzi, S., Tam, S. S., Zareian, G., \& Nimehchisalem, V. (2015). Iranian EFL students' listening comprehension problems. Theory and Practice in language studies, 5(2), 263-269.

Roskelly, H. (1999). The cupped hand and the open palm. The Subject Is Writing, 125-35.

Rubin, J. (1994). A review of second language listening comprehension research. The modern language journal, 78(2), 199-221.

Saha, M., \& Talukdar, A. R. (2008). Teaching listening as an English language skill. Crossings: ULAB Journal of English Studies, 2(2), 193-206.

Sari, R., Putri, S. E., Herdi, H., \& Hamuddin, B. (2018). Bridging critical discourse analysis in media discourse studies. Indonesian EFL Journal, 4(2), 8089.

Solak, E., \& Altay, F. (2014). Prospective EFL Teachers' Perceptions of Listening Comprehension Problems in Turkey. Online Submission, 7(30), 190-198.

Steinberg, S. (2007). An introduction to communication studies. Juta and Company Ltd.

Syaifullah, S. (2019). The Analysis of Students' Ability on Listening Comprehension of TOEFL Test at Sixth Semester Students of English Education Department Lancang Kuning University Pekanbaru. PROCEEDING IAIN Batusangkar, 3(1), 313-322.
Thomlinson, E. H. (2002). The lived experience of families of children who are failing to thrive. Journal of Advanced Nursing, 39(6), 537-545.

Tyagi, B. (2013). Listening: An important skill and its various aspects. The Criterion An International Journal in English, 12, 1-8.

Yilmaza, H., \& Yavuza, F. (2015). The problems young learners encounter during listening skills. ProcediaSocial and Behavioral Sciences, 197, 2046-2050.

Ziane, R. (2011). The Role of Listening Comprehension in Improving EFL Learners' Speaking Skill Case Study: Second Year Students (LMD) at Biskra University (Master's thesis). 